\title{
Negligence and the First Amendment: A Note on the Destructive Assembly
}

Events during the last decade have borne out the prediction that the streets would be a primary forum for protest movements. ${ }^{1}$ As the focus of the complaints has switched from local to national issues, the demonstrations themselves have become national phenomena, attracting hundreds of thousands of participants throughout the country. ${ }^{2}$ During the 1960's the Supreme Court has had ample opportunity to reconsider the problems raised by speech in public places and it does not appear to have disavowed the view that the streets are a proper forum for protest. The states have thus been precluded from completely prohibiting the use of the streets for protest activities; prior to an assembly, regulations of only the time, place, and manner of the assembly are permitted. ${ }^{3}$ In addition, the Court has imposed limitations on state regulations of the protest once it is in progress. The Court has reversed the convictions of demonstrators who were arrested because their assemblies have attracted hostile audiences threatening violence. ${ }^{4}$ It has pointed out that " " . . con-

1 See Kalven, The Concept of the Public Forum: Cox v. Louisiana, 1964 Sup. Cr. REv. 1, 2.

2 Compare the crowds which protested local discrimination in Edwards v. South Carolina, 372 U.S. 229 (1963) and in Fields v. South Carolina, 375 U.S. 44 (1963) with the crowds protesting the Vietnam War in Washington, D.C., in November 1969.

3 It has been suggested that the Court's condonation of state regulation of the time, place, and manner of assemblies, Cox v. New Hampshire, 312 U.S. 569 (1941), is the starting point for a broad distinction between the constitutional protections for "pure speech" and "speech plus." In Cox v. Louisiana, 379 U.S. 586 at 555 (1965), Justice Goldberg, speaking for the Court, said that:

We emphatically reject the notion ... that the First and Fourteenth Amendments afford the same kind of freedom to those who would communicate ideas by conduct such as patrolling, marching, and picketing on streets and highways, as these amendments afford to those who communicate ideas by pure speech.

Justice Black, in Cox v. Louisiana, 379 U.S. 559 at 578-9 (1965), would apparently carry this distinction even further and permit states to bar all assemblies from their streets. For a discussion of the doctrinal difficulties with the distinction and a suggestion that "speech" and "speech plus" are both subject to similar convenience regulations, see Kalven, The Concept of the Public Forum: Cox v. Louisiana, supra note 1.

4 The Court's limitation of state regulation of assemblies in progress is typified by Terminiello v. City of Chicago, 337 U.S. 1 (1949). In Terminiello, the Court reversed the conviction of a speaker whose antisemitic speech had further inflamed an already turbulent assembly consisting of both supporters and opponents of the defendant's views. The jury was instructed to find the defendant guilty if it found that the defendant had 
stitutional rights may not be denied simply because of hostility to their assertion or exercise," "5 and it has been suggested that in such situations the state should restrain the crowd and not the speaker. ${ }^{6}$ Only when the location of the protest has shifted from the streets and parks to other less "public" places has the Court removed much of the protection of the first amendment and permitted more substantial state regulation. ${ }^{7}$

The destruction which with increasing frequency accompanies otherwise peaceable street assemblies raises an additional first amendment question which is closely related to those previously considered by the Court: If the Court believes that the first amendment forbids the state to prohibit street assemblies altogether or to break up assemblies which have attracted threatening crowds, to what extent will the Court limit the right of one injured during an unruly assembly to sue the political group that organized the protest? The issue is whether in protecting the individual's interest in his person and property, the Court will give him a veto power over the general discussion. 8 Unlike the other restrictions on assemblies considered by the Court-restrictions directed at conduct within the scope of the first amendment-the law of torts was not designed for the purpose of limiting the exercise of speech in public places. If the Court is to curtail the right of a wrongfully injured party to recover damages

stirred the public to anger, invited dispute, or brought about a condition of unrest. The Court found, $i d$. at $4-5$, that a conviction resting on any of those grounds could not stand:

The vitality of civil and political institutions in our society depends on free discussion. ... Accordingly a function of free speech under our system of government is to invite dispute. It may indeed best serve its high purpose when it induces a condition of unrest, creates dissatisfaction ... or even stirs people to anger.

See also Gregory v. City of Chicago, 394 U.S. 111 (1969); Cox v. Louisiana, 379 U.S. 536 (1965); Edwards v. South Carolina, 372 U.S. 229 (1963); Note, Freedom of Speech and Assembly: The Problem of the Hostile Audience, 49 Colvm. L. Rev. 1118 (1949). But see Feiner v. New York, 340 U.S. 315 (1951).

5 Cox v. Louisiana, 379 U.S. 536, 551 (1965) citing Watson v. Memphis, 373 U.S. 526, 535 (1963).

6 See Feiner v. New York, 340 U.S. 315, 326-7 (1951) (dissenting opinion).

$\tau$ In Adderly v. Florida, 385 U.S. 39 (1966), the Court upheld the conviction of thirtytwo student demonstrators who "sang hymns and danced" to protest the arrest of other civil rights workers. The Court found their conduct analogous to that of the demonstrators in Edwards v. South Carolina, 372 U.S. 229 (1963), which the Court had termed an exercise of "constitutional rights in their most pristine and classic form" when reversing the South Carolina convictions. 372 U.S. at 235. The activity in Adderly lost the protection accorded the activity in Edwards when the location of the protest moved from the state capitol, "[t]raditionally ... open to the public," to a jail, which is not. 385 U.S. at 41 .

8 This is a paraphrase of Professor Kalven's statement of the first amendment libel problem. See Kalven, "Uninhibited, Robust and Wide-Open"-A Note on Free Speech and the Warren Court, 67 Mrch. L. REv. 289, 297 (1968) [hereinafter cited as Free Speech]. 
from a defendant engaged in organizing an assembly, the defendant must demonstrate why his activity should be judged differently from the tortious conduct of others.

In the recent case of Maxwell v. SCLC, ${ }^{9}$ the United States Court of Appeals for the Fifth Circuit considered a suit by one injured during a disorderly assembly against the organizers of the assembly. The court's opinion inadequately analyzed the relationship of the first amendment to the liability of the defendant ${ }^{10}$ in reversing-on a "close question of proximate cause"-the district court's decision that the injury was the result of the defendant-civil rights group's negligence. ${ }^{11}$ The district court decision had proceeded on the theory that an act may be negligent if the actor realizes or should realize that it involves an unreasonable risk of harm to another through the negligent, reckless, or intentional conduct of a third person. ${ }^{12}$

The liability of politically oriented groups to substantial damages in situations analogous to the factual setting of $S C L C$ is largely a function of the scope of the duty imposed on them. The extent to which the Supreme Court would find that the first amendment requires an alteration of normal tort liability when the defendant is engaged in the exercise of free expression depends on a reconciliation of two different approaches taken by the Court to the susceptibility of first amendment actors to general rules of law. ${ }^{13}$

9 4I4 F.2d 1065 (5th Cir. 1969).

10 The court rejected the defendant's contention that the first amendment would alter his standard of care. "If there is liability under a proper application of sound tort principles, the stated objectives of the defendant . . . will be of no consequence. The First Amendment is simply not involved in this case." $414 \mathrm{~F} .2 \mathrm{~d}$ at 1067 .

11 The complicated fact situation in the case makes one hesitant to assume that the court used proximate cause as a "device" to free the defendant from liability without requiring discussion of a complex problem. The SCLC (Southern Christian Leadership Conference) was picketing a store which allegedly had a discriminatory hiring policy and in which customers had allegedly been harassed by store policemen. Part of the picket line broke away and started to rock a stopped car. The enraged motorist emerged, fired two volleys from a pistol and, on the second, injured Maxwell, an observer of the demonstration who had placed himself in a vulnerable position after the first burst of gunfire.

12414 F.2d at 1068. See Restatement of Torts $\$ \S 302 \mathrm{~A}, 302 \mathrm{~B}, 303$. Comment d, illustration 1 , of $\S 303$ gives a situation analogous to the facts of SCLC in which there would be liability.

13 For this comment, it is assumed that the rule of law involved in the case was applied in a nondiscriminatory fashion to the defendant. Cf. Kalven, The New York Times Case: IA Note on "The Central Meaning of the First Amendment," 1964 Sup. C. REv. 191, 196-7. Justice Black has suggested that an unequal application of state regulations to different assemblies involves a violation of freedom of speech as well as of equal protection. In Cox v. Louisiana, 379 U.S. 559 (1965), he criticized a Louisiana ordinance which forbades assemblies for all but labor unions. " $[\mathrm{B}] \mathrm{y}$ specifically permitting picketing for the publication of labor union views, Louisiana is attempting to pick and choose 


\section{The Bifurcated Approach to the Frrst Amendment}

In various contexts the Supreme Court has indicated that first amendment activity enjoys no immunity from a nondiscriminatory application of general rules of law. ${ }^{14}$ An examination of these cases indicates that the Court has taken a bifurcated view of first amendment activity in attempting to reconcile society's interests in the dissemination of information with the state's interest in regulation..$^{15}$ By severing the expressive from the nonexpressive elements of first amendment behavior, the Court has been able to focus on the latter and, apparently, avoid constitutional difficulties. "Impositions based on misconduct," it has assèrted, "can be neutral with respect to the

among the views it is willing to have discussed on its streets . . . This seems to me to be censorship in its most odious form, unconstitutional under the First and Fourteenth Amendments." Id. at 581. Professor Kalven sees the merger of first amendment and equal protection arguments as of "considerable practical importance." Kalven, The Concept of the Public Forum: Cox v. Louisiana, supra note 1, at 29-30.

One analogous problem in the assembly area which seems to exist in Chicago involves the requirement that groups post large liability and performance bonds prior to using public parks. Such bonds do not appear to be required of all groups and seem to serve little purpose save harassment, since the city has a thirty-four million dollar insurance policy which covers any contingency the required bonds would cover. See APRIL 27 INvestigating Commission of the American Civil Liberties Union, Dissent and Disorder 10-11 (1968).

Throughout this comment, references to "rules of law" or "legal doctrines" are made without distinguishing between those embodied in statutes and those which are common law principles. The Court, in considering the immunity of first amendment actors to these rules, has never adverted to any difference in terms of state interest between common law and statutory law. Even the Court's concern for precision of terms has not led it to favor one form over the other. Compare Winters v. New York, 333 U.S. 507 (1948), with Gregory v. City of Chicago, 394 U.S. 111 (1969).

$14 \mathrm{~A}$ business "is not immune from regulation because it is an agency of the press. The publisher of a newspaper has no special immunity from the application of general laws." Associated Press v. NLRB, 301 U.S. 103, 132 (1937) (National Labor Relations Act); Associated Press v. United States, 326 U.S. 1 (1945) (Sherman Act); see discussion at text accompanying notes 17-19 infra; National Broadcasting Co., Inc. v. United States, 319 U.S. 190 (1943) (Federal Communications Act); discussion at text accompanying notes 23-25 infra.

15 The bifurcated view suggested here should not be confused with the two-level theory of speech which the Court has employed in several contexts. See Roth v. United States, 354 U.S. 476 (1957); Beauharnais v. Illinois, 343 U.S. 250 (1952); Chaplinsky v. New Hampshire, 315 U.S. 568 (1942). For a general consideration of the two-level theory in the obscenity area, see Kalven, The Metaphysics of the Law of Obscenity, 1960 Sur. CT. REv. 1.

The bifurcated approach discussed in this comment assumes the existence of expressive and nonexpressive elements in a given first amendment activity, e.g., newspaper publishing, and finds no first amendment inconsistency with a regulation which focuses solely on the latter. The two-level theory of Roth, however, assumes that some forms of expression are so without social value as to forfeit any protection which the first amendment might afford. 
content of the speech involved ... and adjusted to strike a fair balance between the interests of the community in free circulation of information" and in the regulation of potentially harmful activity. ${ }^{18}$

Thus, in Associated Press $v$. United States ${ }^{17}$ the Court upheld an antitrust judgment against the Associated Press which ordered the members of the news-gathering organization to cease following bylaws prohibiting them from selling news to nonmembers and granting each member power to block its nonmember competitors from membership. Rejecting the first amendment defense of the Associated Press the Court ruled:

Member publishers of AP are engaged in business for profit exactly as are other business men who sell food, steel, aluminum or anything else people need or want ... . All are alike covered by the Sherman Act. The fact that the publisher sells news while others handle food does not . . . afford the publisher a peculiar constitutional sanctuary in which he can with impunity violate laws . . . . Formulated as it was to protect liberty of thought and of expression, it would degrade the clear and present danger doctrine to fashion from it a shield for business publishers who engage in business practices condemned by the Sherman Act. ${ }^{18}$

Since the Court found that the antitrust order would not interfere with the freedom to "print as and how one's reason or interest dictates" "19 first amendment considerations were not relevant.

In Murdock $v$. Pennsylvania, ${ }^{20}$ the Court, though apparently rejecting the view that first amendent actors were liable to general rules of law, ${ }^{21}$ seems to have based its invalidation of an ordinance which taxed the door-to-door solicitation of the Jehovah's Witnesses on the fact that the regulation infringed on the expressive element of the defendants' conduct. The majority opinion focused on the incidence of the tax. The Court distinguished a tax on the income of a minister from a tax on his privilege to deliver a sermon. While both involved the taxation of speaking for a fee, the distinction between the two elements would permit the taxation of the former free of first amendment difficulties. Since the Court found that the distribution of religious tracts was itself a form of religious activity

16 Curtis Publishing Co. v. Butts, 388 U.S. 130, 153 (1967).

17326 U.S. 1 (1945).

$18 \mathrm{Id}$. at 7.

19 Id. at 20, n.18.

20319 U.S. 105 (1943).

21 Id. at 115. 
whose "purpose is as evangelical as the revival meeting," the tax fell as a burden on the expressive element of first amendment activity. ${ }^{22}$

Finally, in National Broadcasting Co. v. United States, ${ }^{23}$ the Court rejected the first amendment arguments of the broadcasters and upheld the Federal Communications Commission's prohibition of certain contracts between the broadcasting networks and local radio outlets which precluded the outlet from using the programs of other networks and the network from selling its programs to competing outlets. ${ }^{24}$ The Court distinguished these regulations which focused on specific network business practices from any based on the "political, economic or social views" of the broadcaster which would appear to be constitutionally infirm. ${ }^{25}$

Similarly, it would seem that a determination that a first amendment actor had been negligent in conducting his business or in engaging in other nonexpressive activity would not vary as his "political, economic or social views" changed. The conclusion that such a determination involves no conflict with the first amendment, however, admits of one important qualification predicated on an approach to the first amendment in apparent conflict with the decisions which have adopted the distinction between expressive and nonexpressive conduct.

\section{The Girilling Effect}

\section{A. The Concept}

The Court in the cases noted above refused to immunize first amendment actors from the application of general rules of law. Other

22 Id. at 109. The dissent, while not contesting the validity of the bifurcated approach, indicated that it is a game that more than one can play. Justice Reed felt that the incidence of the tax was not on the expressive element of the defendant's activity. Citing Jones v. Opelika, 316 U.S. 584 (1942), he contended that Pennsylvania was taxing only the "money-making activities" of a religious organization, which did not conflict with the first amendment. Compare the discussion in the text accompanying note 25. The dispute between the majority and the dissent focused on whether the activity taxed should be classified as religious (expressive) or nonexpressive.

There is some indication that the classification of the Witness' solicitation as a religious activity served to distinguish it from the solicitation of magazine distributors which, in Breard v. Alexandria, 341 U.S. 622 (1951), was held not immune from a city ordinance prohibiting such solicitation. Justice Reed, who wrote for the Court in Breard, seems to have rejected the argument of the dissent that the first amendment protects the solicitation of subscribers as well as publication. Id. at 650 . He seems to have followed his own contention in Murdock that the regulation of the money-raising aspects of first amendment activity is permissible. Id. at 642 .

23319 U.S. 190 (1945).

24 The chain broadcasting regulations are described at 319 U.S. at 199-209.

25319 U.S. at 226. For another example of the Court's permitting the regulation of the business practices of first amendment actors, see Associated Press v. NLRB, 301 U.S. 103 (1937). 
decisions, however, indicate that this refusal is severely qualified. In recent years, the Court has employed several distinct but related concepts, which have collectively been termed the chilling effect, ${ }^{26}$, to subject generally accepted legal doctrines to renewed constitutional scrutiny when employed in the context of free expression. The Court has furnished several "examples of legal devices and doctrines, in most applications consistent with the Constitution, which cannot be applied in settings where they have the collateral effect of inhibiting free expression." 27

Though apparently unintentional, this "collateral effect" is assumed to lead to self-restraint in the exercise of first amendment freedoms ${ }^{28}$

26 See Note, The Chilling Effect in Constitutional Law, 69 Colum. L. REv. 808 (1969). The different concepts might be termed self-censorship, first amendment vagueness, and economy of means. Though each shares the general traits treated in the text under the chilling effect, each can be distinguished.

In both the first amendment vagueness and the self-censorship cases, the Court is concerned with a regulation "not because it is aimed directly at free speech, but because in operation it may trigger a set of behavioral consequences which amount in effect to people censoring themselves in order to avoid trouble with the law." See Kalven, Free Speech, supra note 8, at 297; Keyishian v. Board of Regents, 385 U.S. 589 (1967). In the vagueness cases, the problem is caused by ambiguous terminology, see the discussion accompanying notes 41-44 infra, while in the self-censorship cases, some other fault is found with the statute. See, e.g., the discussion accompanying text at notes 46.49 infra.

In those cases which employ a strict economy of means rationale, the Court recognizes that the challenged regulation causes a similarly improper inhibition, but the regulation is invalidated not because of the self-censorship problem, but because a different method of regulation would serve the same state purpose and be less injurious of first amendment values. See Kalven, supra note 8, at 299; Note, Less Drastic Means and the First Amendment, 78 YALE L.J. 464 (1969).

In all three concepts the Court is in effect ordering the state to alter its method of achieving a valid purpose so as to reduce the unintended, collateral effect on free speech.

27 Smith v. California, 361 U.S. 147, 150-1 (1959). "When First Amendment rights are involved we look ... closely lest, under the guise of regulating conduct that is reachable by the police power, freedom of speech or of the press suffer." Ashton v. Kentucky, 384 U.S. 195,200 (1966).

28 An assumption is made at two different levels. First, the Court assumes that one who is considering the exercise of first amendment freedoms is aware of state regulations which might render his conduct criminal. Not only are most political groups sufficiently concerned with state regulation so that it is likely that they rely on the constant advice of counsel, but any other assumption by the Court would seem unreasonable in light of the legal system's refusal to recognize ignorance of the law as an excuse for crime.

The second assumption is that this awareness will inhibit the exercise of first amendment freedoms. If one views the Court as creating a presumption of inhibition, it is unclear whether this presumption is conclusive or rebuttable. See C. MCCormick, HandBOOR OF THE LAW OF EVIDENCE 639-41 (1954). In one recent case the Court seemed to turn the presumption on its head. In Red Lion Broadcasting Co. v. FCC, 395 U.S. 367 (1969), the Court upheld the "personal attack rules" of the Federal Communications Commission which require broadcasters, after an attack upon the honesty, character, or integrity of an identified person during the presentation of views on a controversial issue of public importance, to notify the person of the date, time, and identification of the broadcast, 
and has caused the invalidation of state statutes, ${ }^{29}$ common law rules, ${ }^{30}$ and administrative procedures. ${ }^{31}$

In Speiser $v$. Randall, ${ }^{32}$ the Court invalidated a California statute requiring noncommunist affidavits as a condition for a tax exemption. As the Court construed the tax procedure, the burden of persuasion of loyalty was on the applicant and the affidavit was not conclusive. Without contesting the power of the state to allocate the burden of proof or the normal placement of such a burden on a taxpayer seeking an exemption, ${ }^{33}$ the Court found this placement improper in the First Amendment context:

The vice of the present procedure is that, where particular speech falls close to the line separating the lawful and the unlawful, the possibility of mistaken fact finding-inherent in all litigation-will create the danger that the legitimate utterance will be penalized. The man who knows that he must bring forth proof and persuade another of the lawfulness of his conduct must steer far wider of the unlawful zone than if the state must bear these burdens. ${ }^{34}$

to deliver to him a script or tape of the attack, and to offer him a reasonable opportunity to respond over their facilities. The broadcasters complained that the expense and inconvenience of the rules would "irresistibly" force them to self-censorship and that their "coverage of controversial public issues will be eliminated or at least rendered wholly ineffective." Id. at 393. The Court, apparently pleased at the availability of a contradictory statement by the president of one of the complainants, id. at $393 \mathrm{n} .19$, rejected this contention as speculative. Throwing the burden of proving self-censorship on the broadcasters, the Court stated that "if experience with the administration of these [the FCC] doctrines indicates that they have the net effect of reducing ... the volume and quality of coverage, there will be time enough to reconsider the constitutional implications."

This shift of the burden might be explained in two ways. First, the Court explained in the opinion, id. at 388-90, that the first amendment rights of the listeners and the scarcity of available frequencies limited the rights of the broadcasters and permitted greater government regulation than in speaking or writing. Secondly, the specific regulation challenged seemed designed to enhance the volume of controversial broadcasting. While effectively increasing the expense to broadcasters of expressing certain views, the penalty was not money damages (as in New York Times v. Sullivan, 376 U.S. 254 (1964), discussed at text accompanying notes 59-63 infra), but the airing of contrary views.

29 See, e.g., Smith v. California, 361 U.S. 147 (1959), discussed at text accompanying notes $46-50$ infra.

30 See, e.g., New York Times v. Sullivan, 376 U.S. 254 (1964), discussed at text accompanying notes 59-63 infra.

31 See, e.g., LaMont v. Postmaster General, 381 U.S. 301 (1965), in which the Court invalidated a statute which ordered the Postmaster General to detain all "mail matter, except sealed letters" which he determined to be "communist political propaganda." The addressee, after notification of the detention, could request that the mail be forwarded. The Court found that the deterrence caused by requiring a request for literature which federal officials had condemned as "communist political propaganda" rendered the procedure an abridgement of the first amendment.

32357 U.S. 513 (1958).

33 See Smith v. California, 361 U.S. 147, 151 (1959).

34 Speiser v. Randall, 357 U.S. 513, 526 (1958). 
While such marginal and unintentional deterrence may be permissible with respect to the regulation of most criminal conduct, the Gourt refused to countenance it when speech became the focal point of the questioned activity. Court procedures to punish criminal speech must be "adequate to safeguard against invasion speech which the Constitution protects." 35

Although the Court believes that the method in which first amendment activity is regulated will enter into the calculus of an actor considering the wisdom of engaging in speech close to the "line separating the lawful and the unlawful," not all state regulations with a collateral, deterrent effect on free expression are invalidated. ${ }^{36}$ Only when the potential inhibitions on speech outweigh the state's interest in regulating a certain activity in a specific manner is the rule of law struck. Thus in Shelton v. Tucker, ${ }^{37}$ the Court invalidated an Arkansas statute which required each teacher in the state school system to file annually an affidavit listing every organization to which he had belonged or regularly contributed money within the preceding five years. The Court conceded the right of a state to investigate the competence and fitness of those whom it hired to teach in its schools, and the value of the information disclosed in such an investigation. It held, however, that the breadth of the disclosure requirement and the lack of confidentiality of the lists so jeopardized the right of association of every teacher as to invalidate the statute. "[T] $]$ his Court has held that, even though the governmental purpose be legitimate and substantial, that purpose cannot be pursued by means that broadly stifle fundamental personal liberties when the end can be more narrowly achieved." 38 Since the Court balances the state's interest in the means rather than in the goal of regulation against the interest of all individuals in freely exercising a protected first amendment right which may be deterred by the state's regulatory measures, the test appears to be one heavily weighted against a regulation with an inhibitory effect on speech. The chilling effect doctrine, however, only requires the state to readjust its method of achieving a certain end.

35 Id. at 524.

36 See Note, The Chilling Effect in Constitutional Law, 69 CoLum. L. REv. 808, 822 (1969); Van Alstyne, The Demise of the Right-Privilege Distinction in Constitutional Law, 81 Harv. L. REv. 1451 (1968). See also Communist Party v. Subversive Activities Control Bd., 367 U.S. 1, 88-105 (1960); Barenblatt v. United States, 360 U.S. 9, 125-34 (1959).

37364 U.S. 479 (1960).

$38 \mathrm{Id}$. at 488. In Shelton, the Court took the legislature's stated purpose at face value when suggesting that it could be achieved through the use of a more precise method. Professor Kalven has suggested that the law should be considered in the background of Southern attempts to destroy the NAACP by forcing the public disclosure of its membership. If true, there was no proper method to accomplish this goal. See H. KaLven, THE Negro AND the First AMENDMENT 90-105 (1965). 
Such a requirement does not suggest that the first amendment actor is forever immune from conforming to that end..$^{39}$

The Court has employed the chilling effect in two related ways to discourage the unnecessary deterrence of certain methods of state regulation. First, to permit a more rational evaluation of the consequences of engaging in expressive activity, the Court has attempted to eliminate uncertainty from the actor's calculus. This has added a new dimension to the invalidity of statutes whose vagueness had previously conflicted with the requirement of clarity embodied in the due process clause. ${ }^{40}$

Thus in Cramp v. Board of Public Instruction, ${ }^{41}$ the Court invalidated a Florida loyalty oath which set a standard of conduct which the Court found so vague that "men of common intelligence must necessarily guess at its meaning and differ as to its application." 42 After finding this violative of the " first essential of due process of law," "43 the Court held that "the vice of unconstitutional vagueness is further aggravated where, as here, the statute in question operates to inhibit the exercise of individual freedoms affirmatively protected by the Constitution. ... '[S]tricter standards of permissible statutory vagueness may be applied to a statute having a potentially inhibiting effect on speech, a man may the less be required to act at his peril here because the free dissemination of ideas may be the loser." "44

39 It has been suggested that the Supreme Court has used the void-for-vagueness doctrine in a similar fashion. The vagueness cases "purport to pass upon the legitimacy or illegitimacy of means, invalidating a particular regulation with regard to those as to whom it is indefinite, and because it is indefinite, and reserving judgment as to whether the end sought to be achieved is achievable through more definite regulation." Note, The Void-for-Vagueness Doctrine in the Supreme Court, 109 U. PA. L. REv. 67, 111 (1960). The vagueness syntax serves to indicate the direction state law should take while avoiding questions of "ultimate power." $I d$. at 115 .

40 Due process requires sufficient clarity of statutory standards so that an actor prior to acting and a jury trying him for his actions could "safely and certainly judge the result." Cline v. Frink Dairy Co., 274 U.S. 445, 465 (1927). See Note, The Void-for-Vagueness Doctrine in the Supreme Court, supra note 39 , at 67.69 , and cases cited therein. It has been suggested that the vagueness doctrine has served "less as a principle regulating the permissible relationship between written law and the potential offender than as a practical instrument mediating between, on the one hand, all of the organs of public coercion of a state, and, on the other, the institution of federal protection of the individual's private interests." $I d$. at 81 .

41368 U.S. 278 (1961).

42 Id. at 287, citing Connally v. General Construction Co., 269 U.S. 385, 391 (1926).

43 Id.

44 Id. See also Keyishian v. Board of Regents, 385 U.S. 589 (1967); Ashton v. Kentucky, 384 U.S. 195 (1966); Dombrowski v. Pfister, 380 U.S. 479 (1965); Baggett v. Bullitt, 377 U.S. 360 (1964). Compare Nash v. United States, 229 U.S. 373, 377 (1913). The Court's concern with the impact of vague, speech-related statutes on the decisions of potential actors is demonstrated by its receptivity to the challenges to such statutes. The Court deviates from the normal prohibition against raising the rights of others in permitting those 
The chilling effect has also been employed to provide "breathing space" to first amendment rights. ${ }^{45}$ Thus, the Court has forbidden the punishment of unprotected conduct, engaged in unknowingly, in order to preclude the deterrence of related, protected activity. In Smith v. California, ${ }^{46}$ the Court reversed the obscenity conviction of a bookseller based on a California ordinance which dispensed with the need for proving that the defendant had knowledge of the character of the books he sold. ${ }^{47}$ The statute's invalidity did not result from its direct prohibition of the sale of obscene materials which are not constitutionally protected. ${ }^{48}$ Rather, the Court found that the collateral effect of the statute was to "restrict the books [the bookseller] . . . sells to those he has.inspected; and thus the state will have imposed a restriction upon the distribution of constitutionally protected as well as obscene literature." 49 To prevent the collateral inhibition of the sale of nonobscene material, the Court gave legal approbation to the unknowing sale of the obscene. ${ }^{50}$

A similar approach apparently guided the Court's decisions in the Communist Party membership cases. In Scales $v$. United States, ${ }^{51}$ the Court reiterated its position that one could not be punished for being a member of an organization engaged in unprotected advocacy ${ }^{52}$ un-

charged under an allegedly vague statute regulating speech to challenge the law's clarity as to others. It has been suggested that this is necessary since those improperly deterred by the statute will never appear before the court. See generally A. BrCkEL, THE LEAST Dangerous Branch 149-50 (1962); Sedler, Standing to Assert Constitutional Jus Tertii in the Supreme Court, 71 YALE L.J. 599 (1961).

In addition the Court seems to have found that the mere existence of a vague statute regulating speech provides sufficient injury to give standing to one who alleges an intention to act in a manner arguably covered by the statute. See Note, The Chilling Effect in Constitutional Law, supra note 36, at 811-2; cf. Bantam Books, Inc. v. Sullivan, 372 U.S. 58 (1963). The Court has held that "[t]he threat of sanctions may deter . . . almost as patently as the actual application of sanctions." NAACP v. Button, 371 U.S. 415, 433 (1963).

'These relaxed views of standing and the rejection of the abstention doctrine when speech-related statutes are challenged, see Zwickler v. Koota, 389 U.S. 241 (1967), seem designed to remove vague speech-related statutes as speedily as possible so as to encourage the exercise of first amendment rights.

45 See NAACP v. Button, 371 U.S. 415, 433 (1963). “. . . [T] [Te Court's primary concern [with the first amendment] has been to determine the extent of the right and the surrounding safeguards necessary to give it "breathing space.' " Curtis v. Butts, 388 U.S. 130, 148 (1967).

46361 U.S. 147 (1959).

47 Compare the Court's concession that the absolute liability which it found impermissible in the first amendment area was permissible when applied against suppliers of food, 861 U.S. at 152, with the text accompanying note 18 supra.

18361 U.S. at 155. See Roth v. United States, 354 U.S. 476 (1957).

19361 U.S. at 153.

50 Cf. United States v. Balint, 258 U.S. 250 (1922).

51367 U.S. 203 (1961).

52 "It was settled in Dennis [v. United States, 341 U.S. 494 (1951)] that the advocacy 
less, as in the section of the Smith Act challenged in that case, "clear proof that a defendant 'specifically intends to accomplish the aims of the organization ..." "'53 is required. The Court found that the absence of a scienter requirement would "engender an unhealthy fear that one may find himself unwittingly embroiled in criminal liability" and thereby inhibit the exercise of the right of association. ${ }^{54}$ To protect associations on the borderline of legality, "the state may only seek to root out persons with guilty knowledge of the organization's activities."'55

\section{B. Tort Law and the Chilling Effect}

The law of torts provides a systematic framework for determining the compensation of persons injured by the conduct of others. The imposition of tort liability for particular conduct has fluctuated over time, reflecting a tension between the law's desire to protect the interest of the individual in security and its attempt to foster the individual's interest in freedom of action. ${ }^{56}$ The public's "interest in a particular act may be so great as to excuse ... negligent conduct." "57 If the chilling effect suggests the existence of a conflict between the first amendment and the establishment of a traditional negligence standard for the assembly organizer, an alteration of the standard rather than the complete immunization of those engaged in free expression from tort liability might be the resolution.

A consideration of the application of the chilling effect doctrine to the law of libel indicates the locus of conflict between a negligence standard and the first amendment. ${ }^{58}$ In New York Times $v$. Sullivan, ${ }^{69}$ the Supreme Court overturned a $\$ 500,000$ damage award returned

with which we are here concerned is not constitutionally protected speech, and it was further established that a combination to promote such advocacy ... is not such association as is protected by the First Amendment." Id. at 228-9.

$53 \mathrm{Id}$. at 229. Such specific intent is not required to find proof of a conspiracy. All knowing association with a conspiracy may permissibly be penalized.

$54 I d$. at 229.

55 Note, The Chilling Effect in Constitutional Law, 69 Colum. L. Rvv. 808, 824 (1969). See also Schneider v. Smith, 390 U.S. 17 (1968); Sweezy v. New Hampshire, 354 U.S. 234, 248 (1957); Wiemann v. Updegraff, 344 U.S. 183 (1962).

56 Seavey, Principles of Torts, 56 HARv. L. REv. 72, 73 (1942).

57 Id. at 89.

58 Only a brief discussion of the first amendment libel problem is necessary due to the existing legal literature on the subject. See Kalven, The New York Times Case: $A$ Note on "The Central Meaning of the First Amendment," supra note 13; Kalven, The Reasonable Man and the First Amendment: Hill, Butts and Walker, 1967 Sup. Cr. REv. 267 [hereinafter cited as The Reasonable Man]. In The Reasonable Man at 275, the author reached the apparently premature conclusion that "to a considerable extent, state tort law is limited by First Amendment considerations."

69376 U.S. 254 (1964). 
against the New York Times for a false and defamatory statement it had published concerning the treatment of civil rights workers in Alabama. The Court, which believed that the threat of heavy liability for libel would deter the dissemination of information, ${ }^{60}$ sought to limit such deterrence by altering the basis of liability. It invalidated the rule that a speaker or writer had absolute liability for false and defamatory statements. It held that "the erroneous statement is inevitable in free debate, and ... it must be protected if the freedoms of expression are to have the 'breathing space' that they 'need to survive ...." "61

To reduce the possibility that "would-be critics of official conduct may be deterred from voicing their criticism, even though it is believed to be true and even though it is in fact true, because of doubt whether it can be proved in court or fear of the expense of having to do so,"62 the Court held that the Constitution required proof of actual malice-knowledge that the statement was "false or with reckless disregard of whether it was false or not"-before a public official could recover damages for defamation. ${ }^{63}$

In a related case, Time, Inc. $v$. Hill ${ }^{64}$ the Court explained why a negligence standard provided inadequate protection for a publisher

00 Id. at 277. The Court pointed out that in Alabama, criminal liability for the conduct engaged in by the Times would have led to no more than a five hundred dollar fine and six months in jail, a penalty that contrasted sharply with the large damages awarded in the case, an award which could be duplicated by others who could convince a jury that they, like Sullivan, had been implicated in the advertisement.

New York Times appears to be the first case in which the Court found that the chilling effect could be triggered in a private legal action. Such a finding may have been made easier by the fact that the bulk of the damage award was punitive rather than compensatory. The Court has not, however, limited its use of the doctrine in private actions to those where punitive damages have been awarded. See, e.g., Time, Inc. v. Hill, 385 U.S. 374 (1967).

61376 U.S. 254, 271-2 (1964), citing NAACP v. Button, 371 U.S. 415, 433 (1963).

62376 U.S. at 279.

63 Id. at 279-80. In later cases the Court has expanded the class of victims which the media may libel with a privilege. Not only public officials, but "public figures," Curtis Publishing Co. v. Butts, 388 U.S. 130 (1967), and those who thrust themselves "into the 'vortex' of an important public controversy," Associated Press v. Walker, reported with Curtis v. Butts, supra, must prove more than mere negligent falsehood in order to secure a libel award. In addition, the Court has never rejected the theory that it proposed in Time $v$. Hill that the privilege is operative if the subject of the media communication is "newsworthy." This theory has been criticized, Wright, Defamation, Privacy and the Public's Right to Know: A National Problem and a New Approach, 46 TExAs L. Rev. 630, 632, 636 (1968). See generally The Reasonable Man at 378-90. This expansion indicates that society's interest in the dissemination of information, not the impropriety of seditious libel, is the primary justification for the privilege given the media. The latter was, however, the seminal concept in the area.

64385 U.S. 374 (1967). 
whose liability depended on a jury's assessment of his actions. In Hill the defendant had published a somewhat fictionalized account of an incident involving the plaintiff in its advertisement of a play concerning the incident. The plaintiff sued under a New York statute that the New York Court of Appeals had construed to provide damages to one whose name or picture was used for advertising purposes without his consent. ${ }^{65}$ The Court found that the New York courts permitted liability if the errors in the article were substantial, without regard for the scienter of the defendant. In applying the New York Times malice requirement to the New York privacy statute, the Court explained that

even negligence would be a most elusive standard . . . A negligence test would place on the press the intolerable burden of guessing how a jury might assess the reasonableness of steps taken by it to verify the accuracy of every reference to a name, picture or portrait.... Sanctions against either innocent or negligent misstatement would present a grave hazard of discouraging the press from exercising the constitutional guarantees .... Fear of large verdicts in damage suits for innocent or merely negligent misstatement . . . must inevitably cause publishers to "steer . . . wider of the unlawful zone," ... and thus "create the danger that the legitimate utterance will be penalized." 66

By employing the conditional privilege of New York Times in Hill, the Court indicated that the first amendment policy in favor of the dissemination of information superceded the privacy right of one who had in no way sought to enter the public arena. ${ }^{67}$

By its insistence on malice, the Court appears to have rejected Justice Harlan's argument, suggestive of the cases which distinguish between expressive and nonexpressive conduct, that journalism, like other professional activities of great social value, is subject to a duty of reasonable care. ${ }^{68}$ This rejection of the bifurcation approach may

$65 \mathrm{Id}$. at 381 . The case involved a violation of the plaintiff's statutory right to privacy, not defamation. It is possible that the Court will distinguish between the extent of constitutional protection provided for false and libelous statements on the one hand and false statements which invade privacy on the other. See The Reasonable Man at 270-1 and 289.

66385 U.S. at 389 (emphasis added).

67 See note 63 supra.

68385 U.S. at 410 (concurring opinion). Harlan's argument has only a superficial relationship to the bifurcation cases. Under these cases the research aspect would be considered apart from the content of the article. The standard of care would presumably be the same regardless of the "political, economic or social views" of the publisher. Justice Harlan, however, would create an elaborate scheme in which the standard of care shifts as the nature of the article and the public position of the subject change. See The Reasonable Man at 298-9. 
have been based on the Court's apparent perception in the libel cases that a judgment on the reasonableness of an author's research was dependent upon the nature of the product: the more critical or controversial the article, the more the author should be concerned with the truth or falsity of his charge. ${ }^{69}$ The Court feared that the threat of heavy liability for slight errors in research would lead to a reduction in that type of publication most likely to lead to liabilitythe critical and controversial. Just as the Court found it necessary to give legal sanction to the negligently false statement in order to provide sufficient protection to the critic, it seems likely to find that an intolerable deterrence of peaceable assemblies would result from the punishment of the negligently destructive demonstration. ${ }^{70}$

In a suit similar to $S C L C$, the Court would examine the assembly organizer's preparations as it has examined the publisher's regard for the truth or falsity of his charges. The propriety of the timing and placement of the assembly, ${ }^{71}$ of the arrangements made with city police officials, ${ }^{72}$ and of the communications from the organizers to the

69 See the discussion of the Saturday Evening Post's research for its story on the University of Georgia Athletic Director, Wally Butts, 388 U.S. 130, 156-8.

70 In the libel cases, the Court seemed to ignore the possibility of viewing the problem as one of insurance. The balance between the desire to safeguard first amendment activity and the need to protect personal reputations might appear to be tipped by the fact that a newspaper could more easily insure against the damages resulting from a libelous statement than could the victim. With insurance, the publisher is in effect translating the possibility of substantial damages into a relatively small and certain premium.

It is difficult, however, to speculate on the effect insurance would have on the deterrence of controversiality that would otherwise exist, and the Court may have been reluctant to let the insurance question alter a result apparently dictated by the first amendment. See generally Weiler, Defamation, Enterprise Liability and Freedom of Speech, 17 TORONTO L. REv. 278 (1967); Reasonable Man at 302 n.104. The unwillingness to speculate on the impact of insurance on first amendment activity would very likely lead the Court to ignore the possibility of insurance in the context of the destructive assembly. In addition, it is not as clear as in the libel cases that the first amendment actor here is better able to insure against the risk. Unlike the injuries caused to victims of libels, injuries to person and property resulting from destructive assemblies are frequently insured against by the victims.

71 See note 4 supra.

72 As the issue espoused at an assembly changes, so will the foreseeability of third-party conduct and the need to guard against such conduct. Certain assemblies seem more likely than others to generate violent opposition or to attract disorderly support.

Preparations with the police prior to the assembly might include notifying them of the potential number of participants and discovering how the police will react to certain conduct, i.e., picketing by four rather than two abreast. If such information is communicated to the participants it may serve to prevent the surprise which often contributes to a tense situation. If the demonstration is a large one, the selection of some of the participants to act as parade marshalls and to assist the police in governing the demonstration may serve to reduce tension by reducing the number of face-to-face encounters of police and protesters. See Transcript at 15243-8, United States v. Dellinger, 69 CR 180 (N.D. IIl., Feb. 20, 1970). 
assembly participants ${ }^{73}$ depend, at least in part, on the controversiality of the issue espoused. An assembly organizer who must risk a jury's assessment of the reasonableness of precautionary preparations that he has taken is as apt to cease activity which the state could not prohibit directly as is the newspaper publisher whose plight worried the Court in New York Times. To the extent that the standard of care of a first amendment actor seems likely to affect his inclination to espouse controversial doctrines, the chilling effect concept indicates that it must be set closer to intention than to mere negligence. ${ }^{74}$

\section{CoNCLUSION}

The problem of injuries caused by unruly assemblies raises the question of whether the Court's limitations of state regulations designed to reduce the use of the streets for protest will lead it to alter normal tort liability for the assembly organizer. The chilling effect cases indicate that the first amendment requires an alteration of the normal negligence standard because the level of the duty imposed will affect the content of the expression. A mere negligence test would place on the assembly organizer an "intolerable burden" of estimating a jury's assessment of the reasonableness of his preparations. The chilling effect cases would, therefore, limit the scope of those decisions which apparently permit the application of general rules of law to the nonexpressive aspects of first amendment activity to those situations in which such an application does not depend upon consideration of the expressive element.

73 By "communications" more is meant than the inflammatory remarks addressed by the speaker to the crowd. Compare note 4 supra., Communication of an informative nature would seem to be an important part of any assembly. Thus, an ACLU Committee which investigated a disorder at a peace demonstration in Chicago found that the failure of the city to provide a promised speaker system made it impossible for most of the assembled marchers' to learn the conditions of the parade permit issued. This ignorance was seen as one cause of the disorder. See DISSENT AND DisorDER, supra note 13, at 20-21; compare note 71 supra. If the absence of the equipment had been the responsibility of the organizers of an assembly whose participants were apt to react adversely to the imposition by police of unannounced conditions, grounds for liability would arguably be present.

74 In the libel cases the Court failed to make clear how close to intention the standard must be in order to provide sufficient "breathing space." It has been suggested that while the Court theorized that all but calculated falsehoods should be protected, the standard of care it ultimately proposed embraced " 'reckless disregard of the truth,' a concept which belongs to the negligence family." The Reasonable Man at 305 .

An example of a situation in which the standard of care set will not inhibit the first amendment actor's expression is the liability of a newspaper publisher for the injuries of a pedestrian who slipped on ice which had negligently accumulated on the defendant's sidewalk. Such liability is not apt to have that collateral deterrent effect on the exercise of expression which has troubled the Court in the chilling effect cases. 